\title{
Travel in Black and White: James Baldwin's Equal in Paris
}

\author{
Oana Cogeanu
}

\begin{abstract}
After leaving the United States for Europe, James Baldwin reports of having discovered what it means to be a 'Negro American'. Baldwin's paradoxical discovery of black America in Europe forms the substance of his first published volume, Notes of a Native Son (1955). This paper focuses on one of James Baldwin's most interesting and least approached travel texts, namely "Equal in Paris", in order to find out what being a 'Negro American' means to Baldwin. In other words, the paper aims at investigating the formation and re-presentation of (African-American) racial identity on an ethnically foreign background through travel (and) writing.
\end{abstract}

Index Terms - James Baldwin, equal in Paris, travel, race, blackness, African-American.

\section{INTRODUCTION: A BLACK OR WHITE APPROACH}

James Baldwin sought racial invisibility by leaving the US for Europe and ended up becoming the most visible black American writer of his time. Half in earnest, one can subscribe to Bell's assessment that Baldwin spent the first part of his career compensating for his deprivation and the second part compensating for his success [1]. What Baldwin has become, the scholar claims, he travelled four thousand miles not to be: a 'Negro writer' [1]. In consequent irony, white and black scholarship on James Baldwin never tires to root the author's identity in color, either by emphasizing the writer's allegiance to blackness in his essays or by stressing the conversion to whiteness in his fiction. In both cases, an essentialist causal relation emerges: the value of Baldwin's work is due to, or ignorant of, his blackness; interestingly, its literary value is no subject to controversy.

Among those for whom James Baldwin's canonicity is a consequence of his blackness, Dupee affirms that "as a writer of polemical essays on the Negro question James Baldwin has no equals," but plays down his assessment by adding that the essayist "probably has, in fact, no real competitors" [2]. Baldwin is seen by Dupee as "the Negro in extremis, a virtuoso of ethnic suffering, defiance and aspiration," whose role is that of the man whose complexion constitutes his fate. The scholar subsequently draws a little explained, yet appealing comparison in claiming that Baldwin wears his color as Hester Prynne did her scarlet letter, proudly; and like her, "he converts a thing so absurdly material in itself into a form of consciousness, a condition of the spirit" [2]. It

Manuscript received January 4, 2014; revised March 11, 2014. This work was supported by Hankuk University of Foreign Studies Research Fund of 2014.

Oana Cogeanu is with the Hankuk University of Foreign Studies, Seoul, Republic of Korea (e-mail: oa_na_co@yahoo.com). remains to be seen whether the scarlet letter, a sign of the ironic synonymy of sin and redemption, fits to some extent Baldwin's inscription of blackness. However, the scholar's conclusion that Baldwin, believing himself to have been branded as different from, and inferior to, the white heterosexual majority, will make a virtue of the situation is only partly accurate: in fact, the writer will make a virtue of his situation of being different from the white and from the black, as well as from the heterosexual and from the homosexual, and therefore having a truly singular vantage point.

Among those for whom James Baldwin's canonicity disallows color, Harold Bloom passes the final positive evaluation on Baldwin's essays: "Whatever the ultimate canonical judgment upon James Baldwin's fiction may prove to be, his nonfictional work clearly has permanent status in American literature" [3]. To Bloom, Baldwin is "the most considerable moral essayist now writing in the United States", because, there's the rub, he is comparable to George Orwell as a prose Protestant in stance [3]. The Bloomian canon would never concede that aesthetic value could be coterminous with non-aesthetic message and consequently requires the author's bleaching to the aesthetic bones: Baldwin's value resides in being comparable to Orwell. In spite of his usual purist bias, Bloom is as inspired as always when, in recognising the prophetic tone of Baldwin's rhetoric, he places the writer in the lineage of "Jeremiah, most inward of prophets" since distinguishable for "his individuation of his own suffering, rather than for his social vision" [3]. One should note, though, that Baldwin's own suffering is the very result of his social experience and his vision, more specifically of the clash thereof.

As always in the case of disjunctive thinking, a third way does exist, though it may be more difficult to travel - as Baldwin's own itinerary testifies. The young James Baldwin expatriated to Paris to prevent himself, in his own words, "from becoming merely a Negro; or, even, merely a Negro writer" [4]; in Paris he tried to resolve what appeared to be the necessary choice between individuality and racial enrolment by finding formal and substantial ways not to choose. He consequently claimed to have discovered what it means to be a Negro American and this paradoxical discovery of black America in white Europe forms the theme of his first published volume, Notes of a Native Son (1955). The volume contains a total of ten essays plus an introduction and is divided into three parts, of which the travel-themed Part III features the lesser known Encounter on the Seine: Black Meets Brown, A Question of Identity, and Equal in Paris, as well as the more famous essay Stranger in the Village. 


\section{AN AFRICAN-AMERICAN IN PARIS}

To Baldwin, the writer needs to establish between himself and society a distance that will allow for clarity - a distance that is afforded by travel and writing. Distance is the aim of Baldwin's travel texts written in and of Europe, all of which deal with the itinerant Negro problem: "I have not written about being a Negro at such length because I expect it to be my only subject, but only because it was the gate I had to unlock before I could hope to write about something else" [5] p. 11, hereinafter [5], p. 11.

In moving from the reference of art to the reference of society to the reference of travel, Baldwin orderly approaches in Notes of a Native Son the concentric discourses conditioning the self. Yet beyond the centripetal forces binding the essays, it is one text in Part III of James Baldwin's Notes of a Native Son that shall be closely read here to make up for the critical neglect of its literary quality: Equal in Paris. Among the travel texts in Part III, Equal in Paris stands out for several reasons. One of them is that the text, unlike those preceding and following it, is not an essay. Equal in Paris is clearly of the epic genre: it narrates an episode of the protagonist's life in Paris in which he gets arrested for the alleged theft of a hotel bed sheet, committed by an American acquaintance, and is eventually released after several days spent in jail. Given its relative brevity and one-event focus, the episode could be classified as a travel sketch. As such, it hardly presents a connection with the essays before and after it - except for one common, ethnic element: Paris and the French character. Following the previous abstractions of Paris into the stage for the carnival of racial masks in Encounter on the Seine: Black Meets Brown or the identity limbo in A Question of Identity, Equal in Paris moves in the opposite direction and proposes a story of concrete Parisian events.

A second reason for the text's peculiarity is that this is the first time in Part III when the first person singular is employed. Both Encounter on the Seine and A Question of Identity, in spite of the acute subjectivity of their content, are written in an impersonal manner, with no explicit authorial intervention - which is part of Baldwin's argumentative strategy of presenting personal opinion as general fact. Nevertheless, Equal in Paris belongs to a different genre, the epic, whose conventions bestow authority on personalized accounts, for their appearance of authenticity; hence the choice for homodiegetic narration.

The comprehensive incipit presents the protagonist, the event, its cause and consequence, the time and the place, all in the first sentence, in a detached, objectivizing manner: "On the 19th of December, in 1949, when I had been living in Paris for a little over a year, I was arrested as a receiver of stolen goods and spent eight days in prison" [5], p. 123. Whereas this introductory summary does away with any possibility of suspense, it helps to shift focus from the fable to the subject, from history to discourse. "My arrest came about through an American tourist" [5], p. 123, begins the account of past events, which provides for one more distinction from the essayistic present tense of the other texts in Part III. The setting is one of those sordid French hotels which Baldwin had invoked in A Question of Identity in an argument of the distance between romantic desire and grim reality; here the author provides a description of the place by using sets of related epithets to construct the image of decrepitude (ludicrously grim hotel; enormous dark, cold, hideous establishments; airless, humid, stone-cold halls, etc.), throwing in a French word now and then for local air.

The univocal description of the setting that gives forth "the odor of gentility long long dead" [5], p. 123 is further accentuated in the caricatured image of the ancient Frenchman running the place, whose features are lacking human emotion because "he had stopped breathing around 1910" [5], p. 123. This spectral figure is immobilized in a pose inside a "weirdly lit, fantastically furnished lobby" [5], p. 123 , from where he mechanically greets the lodgers with a stately inclination of the head, a courtesy gesture reminiscent of times immemorial. Hyperbolizing, the narrator cites hearsay (for the strange immediately generates touristic legends) about the old man never having gone farther than the door of his hotel for thirty years, and concedes to that possibility by adding that "he looked as though the daylight will have killed him" [5], p. 124. This almost Gothic atmosphere sets the stage for uncanny events, and the imagery of a world stuck in its decrepit old ways pushes the reader very far from what Baldwin called elsewhere the "legend of Paris".

The focus will immediately change from the hotel, a fixed point in the itineraries of travel writing, to the compensatory site of the Parisian cafe: "The moment I began living in French hotels I understood the necessity of French cafes" [5], p. 124. Unlike the hotel, the cafe affords mobility and interaction to the protagonist, with the correlative disadvantage of making him difficult to look up: "as soon as I was out of bed I hopefully took notebook and fountain pen off the upstairs room of the Flore, where I consumed rather a lot of coffee and, as evening approached, rather a lot of alcohol, but did not get much writing done" [5], p. 124. Some travelers report of writing in the privacy of a hotel room; Baldwin accounts of writing in a crowded cafe - the site differs, and so does the respective public/private nature of their activity, but the image of traveler as writer is common and reveals that the main activity and purpose of the foreign sojourn might be writing. Having established some coordinates of space, the narrator now introduces the triggering event: one night, in one of the cafes, he is discovered by a New Yorker and "only because we found ourselves in Paris we immediately established the illusion that we had been fast friends back in the good old U.S.A." [5], p. 124.

Relocated in the epic genre, Baldwin's irony continues to function on multiple layers like in the essays, but less bitterly so. The familiarity of the "good old U.S.A." sounds strange in Baldwin's phrasing and should be read subversively, since he perceives his home as neither good nor old. Then, what Baldwin is dramatizing here is what he conceptualizes in Encounter on the Seine, namely the encounter between the American and the Negro; although the racially cautious question "How do you feel about it?" does not appear in this case, the illusory nature of the nationalist bonding is made clear, in comical-ironical mood: "This illusion proved itself too thin to support an evening's drinking, but by that time it was too late" [5], p. 124; impressed with the New Yorker's 
picturesque description of his precarious lodging ("the proprietaire was a thief, his wife a repressed nymphomaniac, the chambermaids pigs, and the rent a crime" [5], p. 124), the protagonist promised to find him a room in his, otherwise equally sordid, hotel.

The following few sentences, persistent in mild irony, reveal the protagonist's semi-detached position towards the events and have an anticipatory function; in short, since "Americans are always talking this way about the French", it did not occur to the protagonist that the New Yorker's description is true, that the latter would "avenge himself of the French Republic", and that the vengeance he took could bring about onto himself serious results, "results which were not less dire for being also comic-opera" [5], p. 124. The dire results are contextualized as being just the last within a series of disasters due to the protagonist's foreignness, which he described as no grasp of the French language, nor of the French character. With regard to the latter, he shrewdly attests "I considered the French an ancient, intelligent and cultured race, which indeed they are" [5], p. 125, in order to immediately turn the representation upside down by capitalizing negatively on apparently positive features: ancient glory implies fatigue and probably paranoia; intelligence has its limits in human affairs; "no people come into the possession of a culture without having paid a heavy price for it" [5], p. 125 - an assessment that, though not necessarily true, is quote-worthy; the order and safety connoted by institutions is exasperating and cruel; lofty personalities are inflexible and strange. In a generalizing, essayistic move, Baldwin then concludes on the meaning of culture: "One had, in short, to come into contact with an alien culture in order to understand that a culture was not a community basket-weaving project, nor yet an act of God" [5], p. 125; the definition by negation gradually slides into an affirmation, which, however, refutes more traditional views: culture "was something neither desirable nor undesirable in itself, being inevitable, being nothing more or less than the recorded and visible effects on a body of people of the vicissitudes with which they had been forced to deal" [5], p. 125. In phrasing culture as inevitable heritage, Baldwin subverts the idea of American culture as the object to be attained by the black subject, and in describing it as the mark of history on a body of people, he undermines essentialist views of racial, ethnic or national (self)determination by suggesting that a people is not the maker, but rather the on-going result of its history.

However, the meditative parenthesis, which could be assigned to the protagonist's stream of thought, closes and one is back in the middle of the narrative. The American friend, who is never given a name in the story and thus remain the symbolic trouble-bringing American, takes with him upon moving from his criminal hotel, "out of pique", a bed sheet; the protagonist borrows it (!) to replace his own, which he hangs out on the hall in order to call the maid's attention to the need of eventually changing the bed linen. These may seem useless, prosaic details, but this is exactly how they are supposed to appear; there cannot be much of a story in the itinerary of a bed sheet - unless, of course, some details of its appearance in the protagonist's room were overlooked.
While the reader is still expecting the adventure announced in the incipit, the protagonist is stuck in his room before Christmas, staring melancholically at the walls, considering the relation between lack of money and lack of social entertainment, and wondering in self-irony "as to which would end soonest, the Great Adventure or me" [5], p. 126; he then descends to the American's room, where he is met by two policemen. Given the language barrier, the policemen are presumed to be looking for some gangster, a category from which the protagonist casually excludes himself, having his thoughts rather set on dinner. But another anticipatory sentence is thrown in: "I did not have a drink or go to dinner for many days after this" [5], p. 127. In the same semi-real slow motion, the policemen are reported to climb up to the protagonist's room and, after a few minutes' search, they identify the bed sheet. The discovery is hyperbolized into a bookish metaphor: "We looked at the sheet, on which I read, for the first time, in the most brilliant scarlet I have ever seen, the name of the hotel from which it had been stolen" [5], p. 127. The evidence of the crime is literally inscribed with the scarlet letter of guilt. The situation would be highly comical, and this explains the authorial assessment of it as comic-opera, if it did not develop to be somewhat tragic. The protagonist subsequently attempts a justification - not to the policemen, to whom access is barred by language, but to the reader and himself - registered in the same stream of thoughts technique: back in the US, "taking things from New York hotels was practically a custom, though, I suddenly realized, I had never known anyone to take a sheet" [5], p. 127. At which point he is placed under arrest. The solemnity of the procession of the two "very clearly criminal" lodgers and the two French policemen, under the silent gaze of the ancient hotel owner and his daughter, is a blatant source of comic of excess and the reader can only assume that the protagonist and his companion were as amused as $\mathrm{s} / \mathrm{he}$ is.

Given the presumable lack of gravity of the bed sheet affair, the protagonist's question falls adequately: "But is this very serious?" [5], p. 128. The answer comes rapidly, twice confirmed: "It's nothing at all" [5], p. 128, in an anticipatory irony that has yet to reveal itself. Baldwin's explanation does not clarify things, quite the contrary: "They meant exactly what they said. It was only that they spoke another language" [5], p. 128. However, this does not seem a serious case of the impossibility of (self-)translation and, beginning with the generalization that "In Paris everything is very slow" [5], p. 128, another parenthesis follows on French bureaucracy. Its role is to account for the fact that, instead of being investigated, the two Americans are kept in custody until the next day; thus, the protagonist and his companion (physically present throughout the events, but muted) are placed in a cell resembling a "chicken coop".

Forced to relinquish the thought of dinner - and hunger will become a leitmotif throughout the events - the protagonist delves in thought and begins to experience fear: "I began to realize that I was in a country I knew nothing about, in the hand of a people I did not understand at all" [5], p. 129. It is on this occasion that a suggestion of the protagonist's blackness appears for the first time in the textprovided one does not conflate the empirical author and the implicit author. This person who declares himself 
accomplished in manipulating "the reactions of the white world" and therefore can be identified with the folkloric figure of the trickster is not in possession of the cultural codes underlying his jailers' behaviour; while he assumes a basic similarity to the violence of policemen anywhere, the difference is that he "did not understand these people, did not know what techniques their cruelty took" [5], p. 130. Yet the protagonist is aware of one thing: "That evening in the commissariat I was not a despised black man. (...) For them, I was an American" [5], p. 130. This, however, is not a relief for the Negro, but rather an advantage on the jailers' part, because the word "Americain" conveys to them some specific meaning and produces "far from inaccurate" expectations. By the same logic, so should the word "French" to a one-year sojourner in Paris... Nevertheless, Baldwin's focus here is evidently not the French policeman, nor his American fellow, but himself and his own impossibility to partake of the foreign culture; the question, he continues, "was not what I was, but who. And this question, since a what can get by with skill but a who demands resources was my first real intimation of what humility must mean" [5], p. 130. That is to say that, thrown in jail for a fault he cannot understand in a country he cannot comprehend, the protagonist is also divested of his what-ness, of his essential attributes, that is, his blackness. Since no longer perceived as a "black man", he is unable to resort to, and manipulate, the familiar strategies of racialized discourse and finds himself naked in his who-ness. The vulnerability of his inner self is thus laid bare for humiliation.

The stream of thoughts ends with the night and in the morning the two retained Americans are taken by a van to the Prefecture. It becomes apparent, in authorial afterthought, that the protagonist's questions are answered so as corroborate what he wished to hear, while in fact all the policemen must have known "that nothing would speed or halt the machine in which I had become entangled" [5], p. 130. If so far the mood was one of ironic amusement, the night in jail and the anticipatory comments set in an atmosphere of gloom, where only bitter authorial irony persists: "They knew I did not know this and there was certainly no point in their telling me" [5], pp. 130-131. The conflation of narrative frequencies is most evident in this allusion to the knowledge acquired between the time of the events and the time of telling, a knowledge already held by the French actors and soon to be shared with the reader.

Forced to dismiss again all thoughts of lunch, the protagonist is first placed in a tiny cell, then taken to an office for a chilling interrogation, is subsequently made to sign a report whose content is foreign to him, is then taken back to the cell and passes on the way by the vindictively-winking owner of the tragic bed sheet, at which point the dim realization comes to him "that we had no way of controlling the sequence of events and could not possibly guess what this sequence would be" [5], p. 131. At this point, too, the gloominess of the scenes is beginning to gain a Kafkian quality. The individual feels prey to the illogical, unpredictable workings of the system. In Kafka, this is a metaphor of the general human condition; in Baldwin, it is the situation of the American Negro in Paris caused by a complex of events involving a mere bed sheet. The absurdity of the situation is similar and so is its contextualization in the legal system, but Baldwin's story adds a smirking twist.

Any scenarios the protagonist projects based on his experience and logic will be thwarted by the dehumanizing mechanism of the (French legal) system. Hours after the conclusion of the "proces-verbal", he is taken through a Kafkian maze of steps and corridors to the top of the Prefecture building, where he is fingerprinted and photographed. The scene presents in cinematic technique another instance of the impossibility of making sense (of faces, which are cruel and indifferent, of voices, from which all human feeling had fled, of speech, which is probably describing in French the retainee's public characteristics but signifies to the protagonist an unintelligible intrusion in his most hostile secrets).

Once the photo is taken, he is led downstairs to the bottom of the building, in a very literal descensus ad infernum: the sight before his eyes is that of a Dantesque purgatory. In the great enclosed shed at the bottom of the building "the very scrapings off the Paris streets had been gathered" [5], p. 133, and the narrator describes the spectral appearances of the doomed inhabitants, offering a typology thereof: old, life-drained men, mature bodies devoid of human content, young bodies hardened in cruelty, and, an ethnic category, North Africans "who seemed the only living people in this place because they yet retained the grace to be bewildered" for no longer being in Africa [5], p. 133. A visual and psychological climax follows: "There was a great hole in the center of this shed, which was the common toilet. Near it, though it was impossible to get very far from it, stood an old man with white hair, eating a piece of camembert" [5], p. 133. This may not be a typical punishment in Dante's purgatory, but the synestesic juxtaposition is terrific in its connotations of dehumanization. And its effect on the protagonist is radical: "It was at this point, probably, that thought for me stopped, that physiology, if one may say so, took over" [5], p. 133.

Accounts of prison experience commonly include a turning point where one confronts one's own corporeality; there are two possible reactio5: surrender and transcendence. One can be crushed by the multiple penitentiary violence upon the body or one may attempt to dislocate oneself from the violated body and thus free one's mind. The protagonist's somatic reaction to the sight of the prison purgatory falls within the former category, and his consequent destitute thoughts are a reflection of the violence of that initial impact. There is no self-pitying exaggeration here, as the protagonist sees no end to his confinement: "...my mind flew back to that home from which I had fled. I was sure that I would never see it any more" [5], pp. 133-134 and realizes the tragic irony of his situation, as he finds imprisonment in his escape: "my flight from home was the cruelest trick I had ever played on myself, since it had led me here, (...) lower, far, than anything I had seen in that Harlem which I had so hated and so loved, the escape from which had soon become the greatest direction of my life" [5], p. 134. The experience of the purgatory only lasts for an hour but, in spite of the protagonist's emerging hope of being freed, he is taken to a police wagon, in whose claustrophobic containment, suggested by the insistent repetition of the adjective "narrow", he breaks down in tears. Crying is here a sign of despair at the 
human's impossibility to control or even predict the workings of the system.

Taken, for incomprehensible alphabetic reasons, to the "better" prison called Fresnes, separated from his "colleague in crime" and divested of all personal effects, which demoralizes him further, the protagonist is locked in with six other "adventurers". The account persists in irony, made possible by the distancing between the events and their narration, yet the protagonist's mood is far from ironic. His absurd "affaire du drap de lit" [5], p. 135 naturally elicits "the wildest amusement or the most suspicious disbelief" [5], p. 136 to his cellmates, none of which, however, is incarcerated for much more serious reasons but who all regard in more detachment the fact of their arrest, taking it "as I would have liked to take it, as simply another unlucky happening in a very dirty world" [5], p. 135. His own outpour of emotion prompts the protagonist to realize the failed idealism of his outlook: "For, though I had grown accustomed to think of myself as looking upon the world with a hard, penetrating eye, the truth is that they were far more realistic about the world than I, and more nearly right about it" [5], p. 135. The resulting distance installing between him and the inmates is due to the protagonist's personal inability to accept the fact of his imprisonment, yet it is put down by the cellmates to his cultural difference, his Americanness.

The experience of imprisonment is represented as reducing humanity to its vital functions; not only does the prison match the protagonist's worst film-based prior representation, it also brings it to life and inflict it on his body, as rendered in the minute registration of violently discomforting thermal, visual, tactile and taste perceptions. Caught in a circular time of undistinguishable days, only marked by morning and evening rapping on the door, the protagonist exists in a vegetative state, his mental functions sunken in the subconsciousness of nightmares. In this suspended state, the mirage of a good meal remains throughout the text the leitmotif of civilization and freedom.

On the third or fourth day, he hears his name called in the foreign language that now connotes to him all possible dangers: "I did not know what interpretation to put on the word 'extrait"' [5], p. 137. His cellmates' amusement in telling horror tales of the inefficiency of French prisons that may even extend to confusing those to be tried with those to be guillotined is to the terrified protagonist only a further source of fear: "... though I knew they were teasing me, it was simply not possible for me to disbelieve them" [5], p. 137. The confrontation with the absurd suspends all logic. However, the protagonist is not guillotined but taken to the Palais de Justice, where he spends the day in waiting - first to be tried, then to be taken back to prison. Having regained some hope that the ordeal might end, he observes critically the court proceedings in which judge, lawyer and prisoner seem to participate mechanically, to a pre-established end of putting offenders where they could not be seen - not because of the offensiveness of their crimes, but because "they did not wish to know that their society could be counted on to produce (...) a whole body of people for whom crime was the only possible career" [5], pp. 138-139.

Whereas this analytical parenthesis is duly occasioned by the protagonist's observations and, as all the other such parentheses in the texts, is textually justified given the chronological and situational distance between what is narrated and the narration, one can also credit in each and every case an authorial intervention in which the implicit Baldwin capitalizes on the events and interprets them in hindsight; here he steps in to show that such a society, at once rigid and unstable, cannot present to the hypothetical young man "the so-well-advertised right path" [5], p. 139. This is a chilling view of the legal system as a means by which society represses its violent instincts rather than acknowledges and sublimates them, through a policy of rehabilitation. Prisons thus become the confines of the society's subconscious, and such a self-repressive system can only lead to social disease. This generalization derived from the observation of the French legal system is then employed to bear testimony to a very subjective assessment of French human nature: the repressive attitude reveals to the author, in the best and worst of senses, the "renowned and spectacular hard-headedness" of the earth's least sentimental and most proud people" [5], p. 139.

The stream of thought is interrupted by the call to trial, which is postponed for after Christmas when the court realizes the necessity of interpreters. As this prompts the protagonist back into a state of irredeemable passivity, a saviour appears ex machina: an old cellmate who is acquitted asks insistently if he can do anything for those remaining; with little hope, the protagonist gives him the phone number of an attorney friend and his own name; this affirmation of his who-ness will bring about salvation. Upon the attorney's reassuring visit the very next day, the protagonist finally realizes the relative magnitude of his misfortune: " $\mathrm{He}-$ my visitor - injected into my solitary nightmare common sense, the world, and the hint of blacker things to come" [5], p. 141. Having managed to re-establish some contact with the world in the promise of an attorney, a pack of Lucky Strike and the prospect of a fine post-Christmas dinner, the protagonist feels he has regained some control over himself.

On Christmas day, restlessly unable to endure the cell and feeling that "the day demanded a gesture" [5], p. 141, he attends the Mass, for no other reason than to hear some music. The description of the experience provides another visual and psychological climax in the essay: "But I found myself, for a freezing hour and a half, locked in exactly the same kind of cubicle as in the wagon which had first brought me to prison, peering through a slot placed at the level of the eye at an old Frenchman, hatted, overcoated, muffled, and gloved, preaching in this language which I did not understand, to this row of wooden boxes, the story of Jesus Christ's love for men" [5], p. 141. Desirous of transcending his imprisonment, the protagonist finds himself physically, visually and linguistically immobilized into the irony of the religious discourse on God's love for humans told inadvertently to a dehumanizing row of wooden boxes. The message of the mass becomes devoid of meaning since it so blatantly excludes its own audience - and this cannot but remind of the African-American trope of the talking book.

The next day is spent in games and the following day in trial, which is readily dismissed. Once the story is told, its effective communication miraculously frees the imprisoned: "The story of the drap de lit, finally told, caused great 
merriment in the courtroom" [5], p. 141, notes the retained. Yet this freedom cannot compensate for its ensuing realization: the laughter in the courtroom reminds the protagonist of the laughter he had often heard at home: "This laughter is the laughter of those who consider themselves to be at a safe remove from all the wretched, for whom the pain of the living is not real" [5], p. 141. Having been so arbitrarily forced to experience the pain of the living, the protagonist can more fully realize the cruel hierarchy of this social and psychological distance. It is this hierarchy that his flight from home was trying to subvert: "I had heard it so often in my native land that I had resolved to find a place where I would never hear it anymore" [5], pp. 141-142. Nevertheless, the absurd bed sheet affair affords a revelation at once constricting and freeing: "In some deep, black, stony, and liberating way, my life, in my own eyes, began during that first year in Paris, when it was borne in on me that this laughter is universal and never can be stilled" [5], p. 142. There is some paradoxical reassurance in that the protagonist's personal tragedy is the classical tragedy of oppression inherent in the human condition.

Indeed, Baldwin's story of imprisonment could be considered to meet the classical, Aristotelian standards of tragedy. In Aristotle's view, if the individual's downfall is brought about not by his own mistake but by an external cause, such as gods or society, what results is misadventure, not tragedy. At first glance, the hero seems more pathetic than tragic in his falling prey to the system and in his insistence on suffering. But the fault triggering the hero's downfall in Equal in Paris is not the working of a malevolent external force; it is of the protagonist's own, albeit unconscious, doing. His mistake is of the hybris kind and lies in the presumptuous attempt to escape his lot. The series of events thus provoked without his knowledge and beyond his control provide to the protagonist, by exposing him to extreme situations, a personal catharsis when he realizes they are a comparatively bearable misfortune. The incidents arouse pity and fear in the hero himself and, correspondingly, in the reader. In addition, the hero eventually achieves a revelation or recognition, what Aristotle called an "anagnorisis" about human destiny. This is the protagonist's final realization of the general human condition and of his own mistake in trying to elude it. In Paris one is equal in tragedy. Fortunately, whereas the tragedy of human condition is permanent, its Parisian dramatization only lasts few days and does not end in the customary death of its protagonist.

\section{CONCLUSION: OF AMERICAN COLORS}

In his time, James Baldwin culturally consecrated the competing racial claims of (black American) inheritance and (American) birthright, the former limited and limiting, the latter vast and boundless, as the access gate to what W.E.B. $\mathrm{Du}$ Bois called the "kingdom of culture" [6]. However, a number of figures in the post-Harlem Renaissance made their way to the kingdom of culture through other gates than James Baldwin, by constructing a significantly different relation to their roots. Charles Johnson, for instance, affirmed polemically that "all knowledge, all disclosure, all revelation from the past, from our predecessors, black, white, and otherwise, is our inheritance... Any sense that other human beings have made out of the world... all that is what we have inherited as human beings" [7]; hence there is no striving to enter the kingdom of culture, for one is already in residence. Whereas, as Posnock argued [8], in historical hindsight Baldwin's troubled black dialectic of birthright and inheritance may become less relevant, it continues to provide an idiosyncratic insight into what could be described as the mirror stage of (African-) American identity formation: the recognition of the other (within). Even progressive intellectuals of the Harlem Renaissance "never really understood the importance of black history and culture to the United States" and did not regard "the relationship between whites and blacks as central to the story of the republic" [9]; the white immigrant and frontier experiences were central to an Americanism unaware of the centrality of the self-other confrontation in its emergence. It took James Baldwin to highlight the role of the white-black dialectic in the making of an American identity.

As a result, James Baldwin has often been said, in accusatory tone, to speak mostly to a white readership, and that is true in the sense that the message he conveys is shaped for both white and black ears. Through Baldwin's discussion of the color line, the question of color identity comes to pose the deepest epistemic and ontic questions not only to the African-American, nor only to the black writer who flees to Paris in order to avoid it, but also to his apparently sheltered white readers, pushed out of what Butterfield calls their tragic innocence. Americans who are ignorant of black identity are ignorant of their own, warns the scholar, much like Baldwin [10].

Then, it can be concluded that Baldwin's canonicity derives not from his or the scholars' choice of a colored or colorless reading, but from the impossibility of a choice between one's allegiance to one's self and to one's culture, between the personal and the political. Baldwin's failure to conciliate with his own color-bound identity situates the writer in a tense position in-between. From this position, Baldwin serves as a mediator, explaining the Negro to America by translating his experience into American terms, by establishing the black's struggle for identity as tantamount to the American's. What Baldwin learned in Europe was the impossibility of drawing a clear distinction between one's self and one's culture. In Europe, Baldwin negotiates a privileged position for himself by claiming an American identity (while declining the guilt for prejudice), and simultaneously embracing the Negro identity (while declining the burden of prejudice), offering the endless search for identity as their common denominator.

\section{REFERENCES}

[1] P. K. Bell, "Coming home," in James Baldwin, Ed. Harold Bloom, New York/New Haven/Philadelphia: Chelsea House, 1986, pp. 109-112, p. 114.

[2] F. W. Dupee, "James Baldwin and 'the man'," in James Baldwin, Ed. Harold Bloom, New York/New Haven/Philadelphia: Chelsea House Publishers, 1986, pp. 11-6.

[3] H. Bloom, "Introduction," in James Baldwin, Ed. Harold Bloom, New York/New Haven/Philadelphia: Chelsea House Publishers, 1986, pp. $1-11$.

[4] J. Baldwin, "The discovery of what it means to be an American," in Collected Essays, by James Baldwin, Ed. Toni Morrison, Literary 
Classics of the United States New York, NY: Library of America, 1998, pp. 137-142, p. 171.

[5] J. Baldwin, Notes of a Native Son, New York, NY: The Dial Press, 1963, pp. 123-142.

[6] W. E. B. D. Bois. The Souls of Black Folk. Cambridge. USA University Press - John Wilson and Son. 1903 http://docsouth.unc.edu/church/duboissouls/dubois.html, p. 7.

[7] J. Little, "An interview with Charles Johnson," Contemporary Literature, vol. 34, no. 2, pp. 66, 1993.

[8] R. Posnock, Color and Culture: Black Writing and the Making of the Modern Intellectual, Cambridge, MA and London, UK: Harvard University Press, 2000, pp. 220-260.

[9] G. Hutchinson, The Harlem Renaissance in Black and White, Cambridge MA: Harvard University Press, 1995, pp. 446-447.

[10] S. Butterfield, Black Autobiography in America, Amherst: The University of Massachusetts Press, 1974, pp. 187.

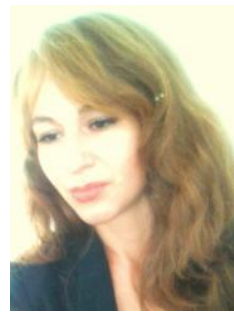

Oana Cogeanu was born in Iasi, Romania, on February 23, 1982. She obtained a bachelor degree in English and Romanian language and literature in 2005 , she was a master degree in cultural studies in 2007, and she get a doctoral degree in philology in 2011 from Alexandru Ioan Cuza University of Iasi, Romania.

She lectured in English language and literature at Alexandru Ioan Cuza University of Iasi since 2008 until 2013, when she became a faculty member of Hankuk University of Foreign Studies, teaching Romanian language, civilization and culture.

Dr. Cogeanu received several research awards and has published articles on semiology, travel writing, and American literature. Her research focus is American literary and cultural studies, with a special interest in travel writing. She is the author of an Introduction to African-American Travel Literature (2013) 